\title{
What does it mean? Students' procedural and conceptual problem solving in a CSCL environment designed within the field of science education
}

\author{
Ingeborg Krange $\cdot$ Sten Ludvigsen
}

Received: 4 December 2006 / Accepted: 9 November 2007 /

Published online: 11 January 2007

(C) International Society of the Learning Sciences, Inc.; Springer Science + Business Media, LLC 2008

\begin{abstract}
This article discusses the relationship between procedural and conceptual problem solving in a computer-supported collaborative learning (CSCL) environment designed within the field of science education. The contribution of this article, and our understanding of this phenomenon, is anchored in our socio-cultural interpretation, and that implies distinctive inputs for the design and re-design of these kinds of learning environments. We discuss institutional aspects linked to the school as a curriculum deliverer, as well as to the presentation of the knowledge domain and the construction of the CSCL environment. The data is gathered from a design experiment in a science setting in a secondary school, and video data is used to perform an interaction analysis. More specifically, we follow a group of four secondary school students who solve a biological problem in a computer-based 3D model supported by a website. Our findings are clear in the sense that the procedural types of problem solving tend to dominate the students' interactions, while conceptual knowledge construction is only present where it is strictly necessary to carry out the problem solving. Based on our analyses, we conclude that this can be explained partly by how the knowledge domain is presented and how the CSCL environment is designed, but that the main reason is linked to the institutional aspects related to the school as curriculum deliverer where its target is to secure that the students actually solve problems that are predefined in the syllabus list. We argue that this affords some particular challenges, linked to making conceptual knowledge constructions in science education explicit in the CSCL environment, and to encouraging the teachers and the school as a curriculum deliverer to give this kind of knowledge construction a prioritised value.
\end{abstract}

Keywords Learning - Scientific concepts · Teacher intervention · Dialogical approach · Design experiment $\cdot$ Interaction analysis $\cdot$ Networked 3D learning environment . Computer-based 3D models $\cdot$ Website

I. Krange $(\bowtie) \cdot$ S. Ludvigsen InterMedia, University of Oslo, P.O. Box 1161, Blindern, 0318 Oslo, Norway e-mail: ingeborg.krange@intermedia.uio.no

S. Ludvigsen

e-mail: sten.ludvigsen@intermedia.uio.no 


\section{Introduction}

The aim of this article is to contribute to the discussion about students' procedural and conceptual problem solving in science, based on empirical studies of these kinds of settings. In addition, the implications are examined relating to what the balance is between these two orientations for the understanding of the design and re-design of computer-supported collaborative learning (CSCL) environments. In line with Andriessen et al. (2003), we argue that this practice-design relationship is crucial for improving CSCL environments in relation to specific knowledge domains.

Our understanding of procedural and conceptual problem solving is linked to Vygotsky's (1986) idea about scientific concepts; a concept is not scientific before it is considered in relation to, or as part of, a larger conceptual system. Students who are procedurally oriented might deal with different concepts, but they do not consider how these are related to the conceptual system. However, on many occasions they can solve the problem, though they will have a limited conceptual understanding of the process. This means that only those students who, over time, can combine the procedural and conceptual orientation and connect different concepts to systematic relationships will appropriate the scientific discourse in a knowledge domain.

Several researchers have in different ways focused on the distinction between procedural and conceptual problem solving in science and mathematics from different theoretical positions (Arnseth 2004; Krange 2007; Kumpulainen and Wray 2002; Lemke 1990; Mason 2007; Moss and Beatty 2006; Roschelle 1992; Vosniadou 1999, 2007). From the cognitive perspective this problem could be seen as a classical problem (Chi et al. 1981). In a recent summary by De Jong (2006), he emphasized that students' articulation of conceptual issues remains one of the most central challenges for the design of learning environments in science. We will briefly look into three of these works, and use these to clarify and position our contribution to the understanding of conceptual problem solving and the designs of CSCL environments for the purpose of improving the conditions for this kind of knowledge construction.

First, Roschelle's (1992) highly acknowledged article Learning by Collaborating: Convergent Conceptual Change, where he analyzed how two high school students constructed an understanding of velocity and acceleration by using a computer simulation designed for this purpose, employed a socio-constructivist perspective as an analytical frame. This implied that he examined how a shared understanding of a problem space was continuously negotiated and established through talk and gestures. He built on a presupposition that students, through experimentation, would make sense of the concepts all by themselves. The task the students were given was to manipulate the position, velocity and acceleration of particles in one window of the simulation, so that it made the same motion as a ball in another window within the same interface of the simulation. Roschelle concluded that conceptual change had occurred through gradual convergence toward a shared understanding among the students.

Second, Lemke (1990) contributed through his book Talking Science-Language, Learning and Values, with a thorough analysis of science discourse. He is concerned with how this discourse is constructed in classrooms over time, and how these discourses have the inherent potential for the teacher to organize for the development of the students' conceptual maps. Based on empirical research on classroom talk, Lemke differentiates between what he labels "thematic patterns" and "conceptual systems." By thematic patterns he refers to the ways in which members of a community tend to use and construe words on a particular subject similarly, from one text or occasion of speaking, to another. And by 
conceptual systems he points towards science teaching, and how language in this particular kind of setting allows for the use of specific thematic patterns of science. Moreover, in line with Vygotsky, he also claims that scientific concepts are interlinked in their meanings, and that it is the use of systems of linked concepts that gives science reasoning its power.

Third, an article previously published in this journal, namely Moss and Beatty's (2006) Knowledge building in mathematics: Supporting collaborative learning in pattern problems, examined, from a constructivist analytical position, how groups of four grade 4 students developed patterns to understand algebraic functions. These students were connected through an ICT based knowledge building environment that was designed to promote a disciplinary inquiry orientation (Knowledge Forum: Bereiter and Scardamalia 1989). Moss and Beatty had designed a set up which consisted of carefully sequenced lessons, and the Knowledge Forum was available for the students during an 8-week period. In this environment the students could post notes, and these constituted the basis for analysis. Moss and Beatty argued that the knowledge building environment was successful as it supported students' disciplinary achievements and was far better than the researchers had expected. The students did not just find rules for algebraic functions, but also managed to generalize beyond this.

Common to all of these interpretations are their concerns about improving students' conceptual understandings of different disciplinary issues within particular knowledge domains. However, there are differences in the three approaches. While Roschelle, Moss and Beatty with their constructivist analytical position highlight the importance of letting students make sense of concepts by themselves, Lemke, from his dialogic point of view, is far more interested in the teacher's vital role in teaching the students to talk science. Moreover, Roschelle, Moss and Beatty have a focus on different CSCL environments, while this is not an issue in Lemke's work. Finally, Lemke is the only one of these three interpretations that includes an institutional level by employing the concept of conceptual systems.

Our interest in procedural and conceptual problem solving in science had to a certain degree an opposite approach to the empirical data than Moss and Beatty had. While they analyzed what they characterized as a success according to the students' disciplinary achievements, we question why the students did not follow up their problem solving in a more conceptual manner during their course. More specifically, we noticed that during a problem solving process that lasted $53 \mathrm{~min}$, one of the students in a group of four asked for a disciplinary explanation of what they were actually doing 12 times, without anyone clarifying this sufficiently. We will stress that a teacher was present during the whole problem solving process, and in line with Lemke, we have been concerned with how this contributed to the students' limited focus on conceptual issues. Moreover, in our study, the students were geographically separated but at the same time linked in a networked computer-based 3D model supported by a website. Both applications, the 3D model and the website, were designed to support science education. Like Roschelle, Moss and Beatty, we were also interested in how these tools structured the students' activities, although we did this in a different manner from them. According to Moss and Beatty, they documented that the students asynchronously improved their notes in the Knowledge Forum, but did not focus on what kinds of efforts made this progress happen. These latter kinds of moment-tomoment interactional issues are at the very core of our analysis. Finally, Roschelle presupposed that the students had understood velocity and acceleration by matching the movements of particles in one window with a ball in another window within the same interface. We share his assumption that they have learned something about velocity and acceleration, but we would at the same time question if this necessarily, as he argues, means 
that the students constructed a conceptual understanding of acceleration and velocity. In the following study we will illustrate that to solve a problem procedurally does not necessarily imply that the students understand the science as a knowledge domain conceptually.

Based on this roughly sketched position to the study of students' procedural and conceptual problem solving in science, the following four research questions have been formulated:

- How does the school as a curriculum deliverer mediate how the students solve a disciplinary problem in a CSCL environment?

- How does the particular knowledge domain mediate how the students solve a disciplinary problem in a CSCL environment?

- How do the computer-based 3D models, and the website designed to support this, mediate how the students, and their teacher, solve a disciplinary problem?

- How do the school as a curriculum deliverer, the knowledge domain, and the computer tools as a cultural means intersect while the students, and their teacher, solve a disciplinary problem?

To sum these questions up, we will analyze how students' interactions are structured by three main means: the school as a curriculum deliverer, the knowledge domain, and the computer tools as a specific type of social practice. Social practice should here be understood as a general concept that gives us a view of historical and institutional aspects, and the moment-by-moment interactions. The issues at stake are to identify both how the knowledge domain can be productively fostered in an educational setting, and to discuss the possible implications this has for the design of computer-supported learning environments. So-called disciplinary productive interactions are here understood as interactions that contribute to conceptually-oriented problem solving.

Our study has its point of departure in a design experiment (Brown 1992; Collins et al. 2004; Furberg and Berge 2003) where collected video recordings of students' interactions were studied according to the premises of interaction analysis (Jordan and Henderson 1995). The experiment was conducted among a group of Norwegian lower secondary school students in a biology class. They were asked to give an explanation of how to use a codontable to read a DNA sequence of a gene (the insulin gene), then to find the corresponding amino acids and combine these into an insulin-protein (this will be explained in detail later). To make them do this we had designed a website to support this kind of knowledge making. They were also asked to employ this knowledge to build a three dimensional (3D) model of the insulin-protein. The 3D model was organised for distributed settings, with the participants connected in a local area network (LAN) and supplied with a telecommunication system that allowed them to communicate orally during the whole session. In addition, we also had recordings of a face-to-face debriefing session, where the students and their teacher were meant to summarize their experiences and finally recordings of some semi-structured interviews were taken.

In the next three sections, a brief socio-cultural interpretation of what happens while a group of students solve a disciplinary problem in a CSCL environment is offered. Secondly, a short summary of the design experiment is given. Finally the main part of this article is the analysis of a group of students' interactions during their disciplinary problem solving, and how these interactions are structured by the school as a curriculum deliverer, the knowledge domain and the tools. Based on these features we describe how their social practice is constituted. The knowledge domain and the tools involved are thoroughly explained during this section. 


\section{Problem solving from a socio-cultural perspective}

Computer-supported collaborative learning (CSCL) research could be categorized into two main strands (Arnseth and Ludvigsen 2006); systemic and dialogical. While the systemic research mainly focuses on outcomes and cognitive aspects of the individual students, the dialogical approach focuses on how tools and resources are used in interaction. In this article the dialogical line of interpretation is followed, and the intention is to contribute with detailed studies of how social and cognitive processes are intertwined (Ludvigsen 2007; Stahl 2006). The intellectual heritage has a strong connection with the socio-cultural perspective (Säljö 2000; Vygotsky 1978, 1986; Wertsch 1991; Wertsch et al. 1995). This means that students' problem solving is made in relation to their cultural, historical and institutional settings, and a main issue is to identify how these differing factors mediate these processes. Moreover, the access to these factors is in interactions, and the unit of analysis is defined to be mediated action (Wertsch 1991). This implies that there is an irreducible tension between the actors' interactions and the mediational tools. In our study, the empirical investigation then focuses on the analysis of how students' problem solving is mediated by the school as curriculum deliverer, the knowledge domain, and the tools.

Language is considered the tool of tools within the socio-cultural approach to learning (Säljö 2000; Vygotsky 1978), and will be used as a basis to study how students approach curriculum based problems as a cultural phenomenon. In addition, different kinds of tools will play a central role in the analysis. These are institutional features, the knowledge domain, and aspects concerning the CSCL environment. The interconnection between these tools can be characterised by tensions or interdependent reinforced tendencies, in the sense that these push the interactions in certain directions. The students will need to perform gapclosing (Lave 1988), in the sense of carrying out actions that aim to make a minimum of social order. This means that they need to find some kind of shared focus in which the relationship between the tools is characterised as a tensional or as an interconnected reinforced tendency. Moreover, the different tools have what we could call meaning potential. We could say that the linguistic meaning is an open potential, and there are non- fixed codes of meaning. Words and sentences are essentially characterized by "vagueness, ambiguity and incompleteness" (Rommetveit 1984, p. 335). The meaning is only half in someone's head because it is always created in interaction with the cultural and historical settings as backgrounds. The meaning potential must be realized through actions (Linell 1998; Rommetveit 1984), and the potential is not necessarily identical to the kind of meaning making which is taking place in situ. This implies that the meaning potential is partly given in advance, and will partly be made relevant as an element of the situated activities (Rawls 2005).

In complex knowledge domains, like the one studied here, the meaning potentials carry a history that is often invisible to the students. This knowledge domain is constructed over extensive periods of time, and only a small part of it is inscribed in the tools. This means that the students only get access to the top of the iceberg of this knowledge base, and what part of this that they manage to realise in practice is an empirical question. Furthermore, these historical elements obviously also follow the institutional characteristics inscribed in the ways that the school deals with curriculum based problems, and the different CSCL tools at their disposal. The students and their teacher have to make judgements about what they find relevant concerning the tools. These judgements are not always the same. Rather, they bring different voices into the problem solving setting, and these are more or less mediated by the cultural tools involved. This issue of the various voices has been characterised as the principle of multiplicity (Ludvigsen et al. 2007). To document this kind of diversity, we aspire to study the students' and their teacher's multiple perspectives, and 
how they nevertheless manage to make some sort of common ground concerning how to solve a disciplinary problem.

Finally, it should be emphasised that all tools, and in particular the computer tools, always come with certain possibilities and limitations. Some of these solve, whilst others add problems within the interactional setting. These problems have been characterised as taxations, and are an encumbrance that follows all tools (Lund 2005; Lund and Hauge 2007; Wertsch 1998). In our study, it becomes vital at an empirical level not only to identify how different computer tools become part of the problem solving process, but also how they obstruct the students' interactions throughout their problem solving.

\section{Method}

This article gathers its data from a gene-technology project at a Norwegian secondary school at the beginning of 2002. The project was arranged as a design experiment (Brown 1992; Collins 1992; Collins et al. 2004; Furberg and Berge 2003; Krange et al. 2000; Roth 2001; Scardamalia and Bereiter 1994). This means that we designed a new type of educational environment, introduced this into an everyday school setting, and conducted studies of how these mediated the students' knowledge constructions in this particular situation. This implies a particular kind of interpretation that can be characterised neither by laboratory experiments nor by naturalistic investigations (Collins et al. 2004).

It is important to highlight that this type of intervention is at the core of the sociocultural perspective. Our intervention is inspired by Vygotsky's (1986) method of double stimulation which stated that "two sets of stimuli are presented to the subject, one set as objects of the activity, the other as a sign which can serve to organize that activity" (p. 56). In the design experiment we presented two sets of stimuli, as such interventions, for the students. One of these was the problem they were asked to solve, and the other was educational hints on how they could organise for this problem solving within the framework of the school as a curriculum developer. By this intervention we intended to promote development at two levels; to give the students' interactions a new direction in a CSCL environment designed to support their biology knowledge, and to make their disciplinary interactions within this environment productive within the framework of how the school deals with curriculum based problems. Both these levels are important, because the development of concepts in Vygotskian thinking is related to both physical objects and their potential for making sense. It is reasonable to expect that a number of tensions or interdependent reinforced tendencies might occur in the empirical setting where the curriculum based problems, the tools, and the knowledge domain mediate the students' and the teacher's problem solving activities. Moreover, it is important to note that the method of double stimulation, as such, is not extraordinary in that new themes and methods are continuously introduced as part of the everyday practice in schools. However, the design experiment differs as a method for double stimulation in that an explicit crucial aspect is to further develop this practice. In our study, this development was the introduction of a new computer-based 3D model of the insulin-protein, and also the introduction to a related website especially designed to support problem solving in relation to this model. Particular to our interpretation of design experiment research, we also consider these initiations in line with the setting that these are meant to become a part of, and in line with how this situation mediates the intended interventions.

The problem solving in relation to the computer-based 3D model lasted three days, and was part of a four week gene-technology project. Three groups consisting of four ninth grade students, and their teacher, were given special attention. The empirical contribution in 
this article is gathered from one of these groups. The groups as such were picked out in collaboration with the teacher, and the only criterion we used was that any real socially disruptive students were left out because of the high cost related to the performance of this kind of design experiment. Data that could be worked with after the data collection period was finished was needed. Three data sources have been used in this study. These are:

- Video recordings gathered from students', and their teacher's, interactions in the computer-based 3D models and their talk related to the website designed to support these. This constitutes the main basis for our analysis, and follows the students during their problem solving stages.

- Video recordings collected from a face-to-face debriefing session arranged immediately after completing the problem solving situation in the computer-based 3D models. This data was used to study what problems they saw as relevant during the problem solving and post problem solving phases.

- Post-test semi-structured interviews of individual students. These are used to document that the students, at least to some extent, had the necessary knowledge to employ the disciplinary knowledge that was introduced, and to consider elements of this in relation to each other. These interviews were recorded and later fully transcribed.

The first set of data needs some further explanation. An intranet solution, where all the students and their teacher where placed in different rooms at the school, one person in each room, was arranged. They shared the same computer-based 3D models and the mentioned website designed to support these. They were also connected through a real-time telecommunication system. These made it possible for both the students and their teacher to interact within the environment, and at the same time talk to each other about what they were doing. All five were present all the time during the problem solving, and the setting was artificial both for the students and the teacher, although they had already solved one main problem in this computer-supported collaborative learning environment. In addition, the teacher received some basic training using these tools ahead of the educational setting.

The distributed location of students and their teacher in different rooms is illustrated in Fig. 1. It is important to notice that the computer-based $3 \mathrm{D}$ models, and the website

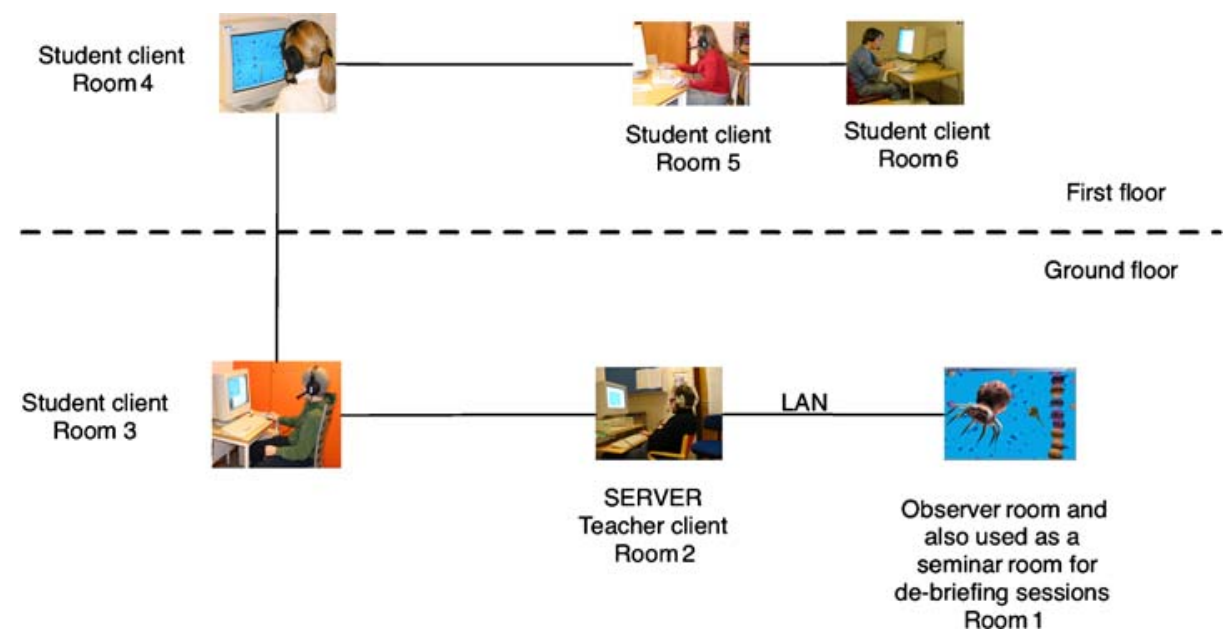

Fig. 1 The distributed location of the students and their teacher in different rooms during problem solving in the computer-based 3D models 
designed to support these, worked as shared objects during the students', and their teacher's, problem solving processes.

All the computers were connected in a local area network (LAN). The teacher's computer worked as a server, and the interface of this computer was extended to an observer room with a video recorder solution. The students' and their teacher's interactions were followed, in the sense of what they did, and what they talked about, in relation to the computer-based 3D models, and according to the website designed to support these. In addition, the recordings made it possible for us to later repeatedly look through the students', and their teacher's, interactions as these unfolded in our video analysis laboratory.

\section{A summary of the data employed during the analysis}

In total, the students solved three main problems using the CSCL tools: Sequencing an insulin gene, building an insulin-protein, and performing a DNA analysis. They spent respectively 90 , 53 and $30 \mathrm{~min}$ on these problems. We focused on the second of these problems to study what happened while a group of students solved a disciplinary problem in a CSCL environment.

Three extracts constitute the basis for the analysis. These are gathered from:

- The first part of the students' disciplinary problem solving where they used the website,

- The very end of the students' problem solving phase where they were employing both the website and the three dimensional models, and finally,

- One extract from a debriefing session arranged just after the distributed interactions had been completed.

The extracts have been chosen because they were informative when trying to better understand the complexity of what the students were doing after, and during, their disciplinary problem solving processes. This means that both the cultural tools, and how these intersect, become visible in the sense that both the interdependent reinforced tendencies and the tension between these became evident. In other words, these were considered as good selections for commenting on further designs of educational settings and computer-supported learning environments.

\section{Analysis and transcription methods}

The analysis is set within an analytical socio-cultural framework, but is empirically driven. The focus is on how a group of students, together with their teacher, solve a disciplinary problem in a CSCL environment, and how this is mediated by different cultural tools (the curriculum based problems, the computer tools, and the knowledge domain). This meant that the empirical evidence and analytical interpretations were considered in relation to each other. Further, the video recordings of the students' and their teacher's interactions provided unique opportunities to focus on temporal organisation of talks and actions, and how these were mediated by the afore-mentioned tools. This kind of analysis, that takes talk and actions as a point of departure, and traces these in accordance with how these evolve moment-by-moment within particular contextual settings, is characterized as interaction analyses (Jordan and Henderson 1995).

The transcriptions were performed as follows: the students' and their teacher's talks were written down as these unfolded on the video recordings. Thereafter, the overlaps were marked in italics, and how the students interacted according to the mediating tools. Words like the expression "all of these," and words that have reference to something that had 
happened before were placed in brackets. Shorter pauses were marked by “...”. Later, each utterance was given a reference number for use in the analyses. The level of detail in the transcripts aims to suit the depth of the analyses, and to create a high level of transparency, so the reader can easily follow the talk and interactions (Mercer 1991). All the names are pseudonyms.

\section{The curriculum based problem, the computer tools and the knowledge domain as mediating tools during the students' problem solving}

In the following analysis, three excerpts are analyzed in accordance with the analytical framework outlined earlier in this article. Before extract one and two, an introduction to the disciplinary problems that the students were asked to solve is given, and as part of this, a description of the tools in use is also given.

The problem: Identifying the correspondence between codons and amino acids

The problems related to how to build a protein are given on the website and take the previous main task, sequencing an insulin gene, as a point of departure. The students had solved some problems related to sequencing the day before. This implies that the students, and their teacher, at least at a theoretical level, should have been capable of considering conceptual elements of sequencing and building a protein in relation, and not just separately. However, whether they actually do this is an empirical question. In this section, we present the main scientific concepts the students needed to make an understanding of, and to later build, a computer-based 3D model of the protein. In this part of the students' interactions they only needed to focus on the website.

Initiated by the teacher, the students started to solve the problem given on the website. This was to find out whether a particular part of a DNA sequence, arranged in codons (see for example ATG, GTA, CCC) corresponded with a chain of amino acids below it (see for example Met, Val, Pro; Fig. 2). These amino acids are parts of a specific protein, the insulin-protein. As an extension of this it is worth mentioning that the figure had both inscriptions that were defined by the knowledge domain, like the codons (ATG, GTA, CCC) and the amino acids (Met, Val, Pro), and educational inscriptions like the arrows that were pointing to different codons and telling them that these were the codons ("starting codon," the "second codon," "the sixth codon").

Fig. 2 The problem the students are asked to solve is to check if the DNA-sequence arranged in codons corresponds to the chain of amino acids that constitutes the first part of the insulin-protein
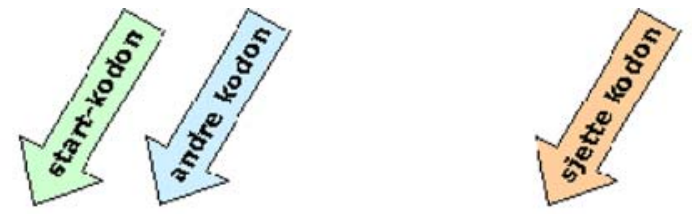

ATG GTA CCC CAC GTA AAA CCA AAA

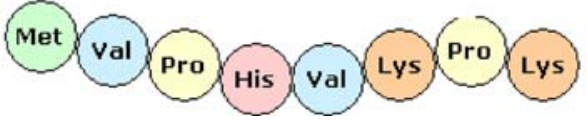


This needs some further explanation. To be able to control this DNA sequence so that it can generate a chain of amino acids, the students needed to find out how to use a codontable. This knowledge was available on the website particularly designed to support students' disciplinary problem solving. Again, we can see how Fig. 3 both has inscriptions that are defined by the knowledge domain like the codontable and educational inscriptions where the table is explained using the codon "GTA" as an example. If the students followed the latter inscriptions they should have a tool (the codontable) for reading the genetic code and for finding the corresponding amino acids. The actual procedure they should have followed was to start by identifying the first letter in the codon GTA. They would have found the letter $G$ that in the example was marked green in the middle of the circle, and then they could have traced the next letter $\mathrm{T}$ that in the example was marked yellow in the next inmost circle, and an A that in the example was marked pink in the third circle. This would imply that they could identify the amino acid Val that in the example was marked blue.

\section{Analysis one-learning scientific concepts_-what is it?}

When we entered the data of three of the students - Pat, Fredric and Mark - they had understood how to use the codontable, while the last one, Cornelia, still struggled. The teacher asked the three first students to explain the relationship between the DNA sequence and the amino acids to Cornelia. Pat had already examined the correspondence between the codon ATG and the amino acid Met, and likewise GTA and Val, when we entered the data. The students needed this procedural knowledge about the use of the codontable to be able to transform a gene sequence into a protein.

Fig. 3 This is a codontable, and it aims to show how to read the genetic code. This entails finding out what codon (GTA) corresponds to a particular amino acid (Val)

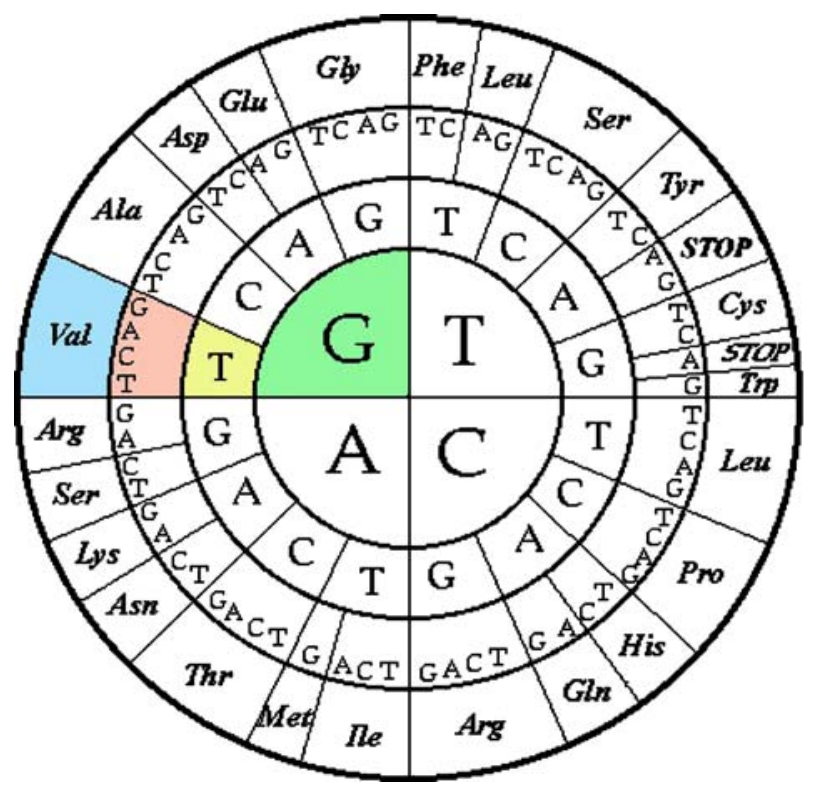


Extract 1: Learning scientific concepts

1. Pat: So-then you can do the same, CCC. Then you have C C C. Pat uses the codontable (see Fig. 3) to examine the relation between the codons and the amino acids in Fig. 2.

2. Cornelia: Then it is Pro. Cornelia is using the codontable (see Fig. 3) to examine the translation of the next codon, $C C C$, in the DNA sequence into an amino acid, Pro, in Fig. 2.

3. Pat: Pro, yes. Then you can do it with C A C. Pat refers to the next codon, C A C, in the DNA sequence in Fig. 2.

4. Cornelia: C A C, then it is His. Now I have got it. Cornelia is using the codontable (see Fig. 3) to examine the translation of the next codon in the DNA sequence into an amino acid, His, in Fig. 3.

5. Pat: Yeah, you got it now?

6. Cornelia: Yes, but I don't understand what it is - what is it?

7. Pat: It is the genetic code. Pat refers to the heading of the website where the use of the codontable is explained (see Fig. 3).

8. Teacher: It is the code. If you are going to build something genetic, then it is the code, the instructions for how you should do it - what protein that should chain together. The teacher uses references from the website; instructions for how you should do it.

9. Mark: Then we...

10. Pat: Have we finished this task then?

The students, and their teacher, follow up the procedural aspects inscribed in the knowledge domain, and in accordance with how the problem they are asked to solve is presented on the website (see Fig. 2 and utterances 1-6). We see that the students, here represented by Pat, follow up the teacher's scaffolding to secure that Cornelia also understands how to use the codontable (utterance 1). In this sense, the teacher both ensures that all the students have the necessary knowledge to continue to solve new problems and that they are actively involved in the problem solving processes. Pat has given two examples where she has used the codontable (see Fig. 3) to identify the codons (ATG and GTA) that correspond with the right amino acids (Met and Val). Now Pat encourages Cornelia to do the same kind of examination of the correspondence between the next codon, CCC, in the DNA sequence (see Fig. 2) and the amino acid using the codontable (see Fig. 3). Cornelia follows up Pat's use of the codontable by suggesting that it is the amino acid, Pro: "Then it is Pro" (utterance 2). Pat confirms Cornelia's solution and challenges her to do the next codon, CAC, in the DNA sequence as well (see Fig. 2 and utterance 3). Cornelia solves it easily and confirms that she has understood how to use the codontable to identify the correspondence between the codon and the amino acid (His; utterance 4). Pat wants to be sure that Cornelia has understood it and asks her if she has got it (utterance 5). Cornelia confirms that she has understood the use of the codontable (utterance 6).

As part of the same utterance (utterance 6), Cornelia questions "but I don't understand what it is-what is it?" She obviously asks for explanations that can clarify what the correspondence between codons and amino acids means beyond the procedural aspects of using the codontable. This is actually the third time out of twelve that Cornelia steps out of the particular problem they are about to solve, by trying to understand what these concepts represent, and what these mean in relation to each other. Pat replies shortly by referring to the website, saying "the genetic code" (utterance 7). The teacher follows up Pat's answer (utterance 8 ). The teacher then tries to go more thoroughly into it by referring to the 
website, and arguing that it is possible to consider this as instructions for how to build something genetically. So far this explanation is right, but then he says "what protein that should chain together" and his use of the scientific concepts become misleading. It is not proteins that chain together but the amino acids, and these acids constitute the protein. Pat and the teacher probably think they have answered Cornelia's question. However they do not follow it up any further, and neither they, nor Mark, make any effort to confirm if she has got an answer she is content with. Rather, they are eager to finish the problem they are asked to solve, and Mark pushes the interactions forward by saying "Then we..." while Pat asks "Have we finished this task then?" (utterance 10).

Extract 1 consists of two main themes; solving the problem (utterances 1-6 and 9-10) and questioning the knowledge domain (utterances 6-8). Relating to solving the problem, the school as the curriculum deliverer is mediating the way Cornelia is included by the teacher, and this was followed up by Pat (utterances 1-6). The teacher knew that the knowledge about how to use the codontable was not only vital for the students while examining the correctness of the correspondence between the DNA sequence and the amino acids while solving this particular problem (see Fig. 3), but that it would also be one of the main issues to solve in the next problem (employing this knowledge in the 3D models). To make it likely for Cornelia to participate well, it was necessary to ensure that she had developed a usable understanding of the codontable. This meant that the teacher not only ensured that Cornelia too would understand how to use the codontable, but also took some kind of social responsibility to ensure that all the students in the group took part and would be able to do so throughout the problem solving processes. The teacher is actually doing a gap-closing intervention here to make a minimum of social order concerning what he considers as the necessary knowledge for all the students to understand while solving the curriculum-based problem (Lave 1988).

Moreover, the school as curriculum deliverer was also mediating what the teacher and Pat legitimized as relevant to talk about. It was the knowledge that was necessary to understand how to solve the problem that was considered valuable for inclusion. Discussions that exceed this were given less space (utterances 6-8) so that the focus of completing the problem solving was viewed as paramount (utterances 9-10). In other words, questioning the knowledge domain in a conceptual sense, going beyond what is conceptually needed to procedurally bring the problem to an end, is not highly esteemed. This is probably why neither Pat nor the teacher spent a lot of time answering Cornelia's question properly. Meanwhile, the teacher goes one step further than Pat by adding an explanation. One interesting issue here is that this is actually wrong. This might be a slip of the tongue, but as the students' trajectory unfolds, it becomes more and more likely that the teacher's attempt to understand the relevant scientific concepts has not been clarified. It is therefore challenging for him to understand and employ the concepts adequately. Moreover, it is remarkable how neither Pat's nor the teacher's explanations open up any follow up questions or confirmations about a shared approach of the scientific concepts. It seems as if Pat and the teacher follow some school practices telling them to listen to and answer questions from co-students, but they are not really interested in resolving differences in interpretations unless these are directly linked to the solving of the problem. The gapclosing concerning relevance is procedurally oriented according to solving the problem, and further knowledge oriented elaborations are suffering compared to this objective (Lave 1988). In this sense, there are some tensions between the meaning potentials rooted in the codontable as a knowledge domain, and how Cornelia tries to follow up some of this knowledge, and the other students', and their teacher's effort to solve the given curriculumbased problems (Rommetveit 1984; Linell 1998). 
Moreover, the knowledge domain of using the codontable is mediating the students' and their teacher's problem solving (utterances 1-6). It becomes clear that their interactions are strongly guided by aspects related to this table. An interesting issue here is that the codontable as a model is based on heavy conceptual knowledge developed over an extensive period of time, but is also simultaneously characterized by some strongly procedural features. The codontable, as a method, can be characterized as procedural, while the scientific concepts that are part of this table pull in a more conceptually challenging direction. An implication of this is that the students, and their teacher, can employ the codontable without fully understanding what the different scientific concepts mean, and how these interrelate. The meaning potential of the codontable is much more comprehensive than what the students relate to, and even get access to, through the computer tools. This double characteristic of the codontable has some tensional implications that are expressed in the relationship between the students' effort to solve the problem (utterances 1-6) and their (lack of) questioning of the knowledge domain (utterances 6-8). In Extract 1, it is the procedural features that characterise the codontable that dominate the students' and their teacher's interactions and what they focus on during their problem solving. As a result, the questioning of the knowledge domain suffers.

Further, the website, where the problem (Fig. 2) and the codontable (Fig. 3) are given, is also mediating the students attempt to solve the problem (utterances 1-6). They examine the relationship between the DNA sequence arranged in codons and the chain of amino acids below it (see Fig. 2), following both the educational inscriptions about how to use the codontable (Fig. 3) and the inscriptions defined by the codontable as a knowledge domain (Fig. 3). Both these inscriptions pull the students', and their teacher's, interactions in a procedurally oriented direction (utterances 1-5). It seems that although the necessary knowledge to answer Cornelia's question is available on the website (utterances 6-8), this is not given space, because her question holds back rather than advances dealing with the problem the students, and their teacher, are about to solve. In Extract 1, it becomes evident that it is not the conceptually oriented questions related to scientific concepts that are being perused, but rather the procedural aspects. This procedural orientation was promoted by how the use of the codontable as a knowledge domain and as a model was arranged during the design procesess, and how this was manifested into the design of the website. Moreover, this implies that the educational inscriptions on the website, explaining for example, the codontable, only support procedural aspects of how to employ this table, while issues that could have been raised to support the students' conceptual knowledge of what this table actually contributes to suffer. As a consequence, the students continue to interact procedurally. We claim that the codontable as a knowledge domain, and the website where this is inscribed, are interdependent reinforced tendencies.

To sum up, this analysis showed that the cultural tools (the school as curriculum deliverer, the specific knowledge domain, and the website) interrelate in ways that partly support and strengthen each other, and partly produce tensions. The school as curriculum deliverer connects neatly with both the procedural aspects related to the knowledge domain of using the codontable, and to the demarcations of the problem on the website that the students are asked to solve. This is also the case for the relationship between the knowledge domain and the website. Meanwhile, the tensions become evident when knowledge-based questions that go beyond the demarcations of the problem are introduced. Then, both the social inclusion and further elaboration of the knowledge domain suffer in relation to the aim of fulfilling the given problem. This means that it is primarily an internal tension in the school as the curriculum deliverer that hinders the students, and their teacher, when they try to follow up elaborations. There is a meaning potential inscribed in the knowledge domain at the website, but this is 
neither explicitly followed up to be viewed as productive in an educational setting, nor is it explicitly integrated in the designs (Rommetveit 1984; Linell 1998). There are definitely priorities among the multiplicity of voices, where those that are related to the fulfilment of the problem are ranked highest, but these are not given in advance (Ludvigsen 2007).

\section{The problem: Building a compute-based 3D model of the protein}

The activities in the computer-based 3D learning environment are linked together by a storyline. The students and their teacher meet in a 3D model of a research laboratory (see Fig. 4). Immediately, they find a professor lying on the floor with a condition of hypoglycaemia. A medicine shelf is open, and all the potions of insulin-protein are destroyed. The teacher tells the students that they are going to help the professor recover, but before they can do so, they have to solve some problems related to making insulin. Figure 4 shows the laboratory just after the students have made the insulin. The hypodermic shows that the standing student is ready to give the professor an injection.

When the students are making insulin they enter another part of the computer-based 3D learning environment. This is at the molecular level of the cells (see Fig. 5). Here the students can pick up fluid amino acids (for example 'Gly', or 'Ser') and place these as pearls in a chain. Where exactly they are going to put the acids is marked by a flickering ball. A long sequence of codons is presented on the website, and to identify the corresponding amino acids, the students have to use the codontable. Moreover, they have to enter the computer-based 3D model and pick these acids up and place them at the end of the chain. The students are represented onscreen by avatars (e.g. the figure in the middle of the picture).

It is important to note that both these computer-based 3D models are objects that the students, and their teacher, share. They can see each other while moving their avatars around and while manipulating the amino acids. They can hear each other while talking through a telecommunication system about what they are doing. This is also the case with the website.

Fig. 4 The computer-based 3D model of the research laboratory. The students and the teacher are represented by avatars designed to look like researchers. The man lying on the floor is the professor suffering from hypoglycaemia. In the bottom right corner a hypodermic with insulin is available

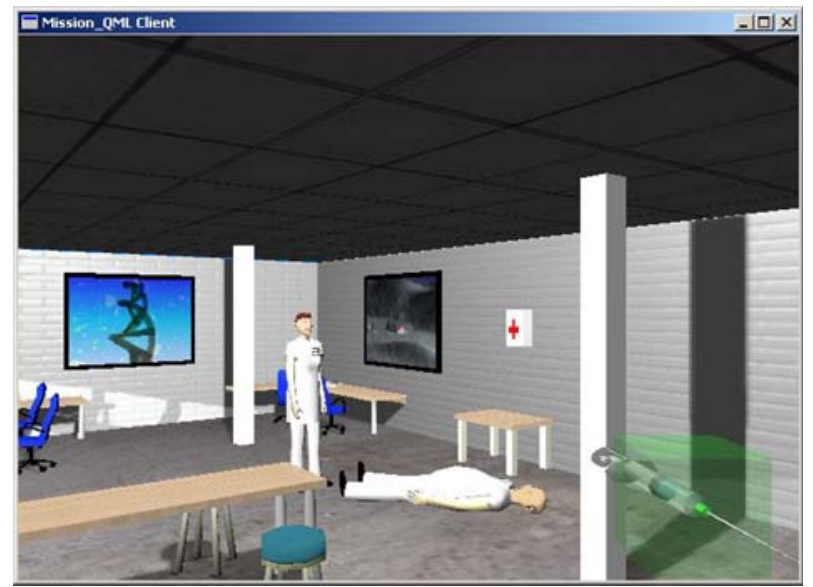


Fig. 5 The molecular level of the cells in the computer-based 3D model of what becomes to be a protein (the chain on the right hand side). The balls that float around are amino acids with different abbreviations (for example 'Gly' and 'Ser'). The students and the teacher are represented by avatars, and here we can see one of these at the bottom of the picture

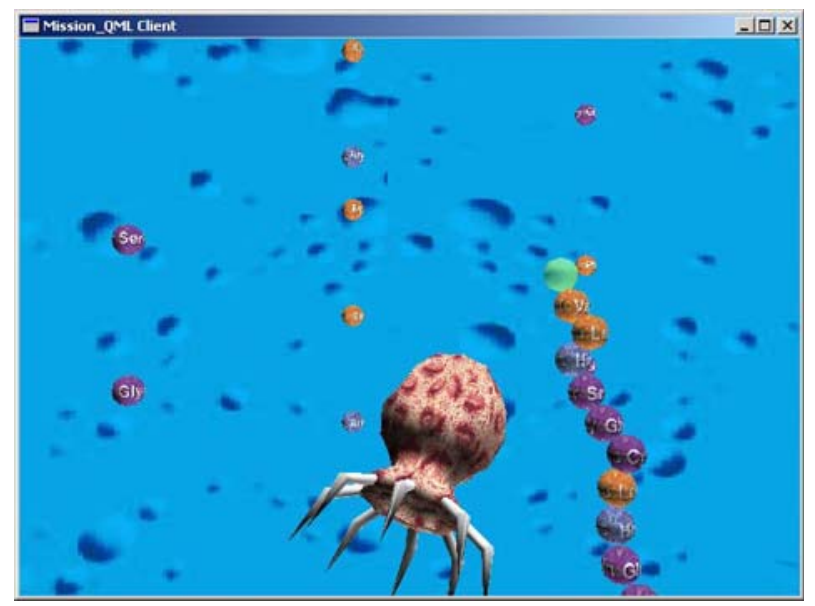

\section{Analysis two: Summing up their knowledge about scientific concepts}

We enter the area of data when the students have completed the building of the insulin protein, and during this process Cornelia has asked a number of times, and in different ways, questions about how the scientific concepts relate to each other. Back in the research laboratory, the students are asked to give the professor an insulin injection, but before doing so the teacher asks the other students to explain to Cornelia what they have just done. Pat follows up, and explains how they identified the correspondence between each of the codons in the long sequences, and the right amino acids, by using the codontable, and how these gradually constituted the insulin-protein. We enter the area of data when Cornelia responds to this repetition of the knowledge domain, and when they are discussing what they have (not) learned.

\section{Extract 2: Summing up their knowledge about scientific concepts}

11. Cornelia: Yes, I understood that, but I didn't understand what, what we build and what these balls are and

12. Teacher: The balls?

13. Pat: They are the proteins in your body.

14. Mark: We have to help that guy. Mark is referring to the professor suffering from the condition of hypoglycaemia. He has located himself in the research laboratory. He has probably also read the last problem on the website where they are told to help the professor.

15. Cornelia: The protein was that the amino acids or something?

16. Teacher: Well, it is a collection of amino acids. That's right.

17. Cornelia: But, but what are these balls then?

18. Mark: But now we are going to solve the next problem, we can't...

19. Teacher: It is acid or protein.

20. Fredric: You - now I have picked up a hypodermic that was placed next to, next to, then I can give it to that guy. Fredric is referring to the storyline. He has located himself in research laboratory and is ready to give the professor an insulin injection (see Fig. 4). 
Again Cornelia confirms that she has understood how they identified the correspondence between each of the codons in the long sequence and the right amino acids by using the codontable, and how these gradually constituted the protein (utterance 11). What she has not understood though, is how different parts, "these balls," are linked to the whole picture of "what they are building" (utterance 11). This might mean two things; either that she does not understand the relationship between the scientific concepts (amino acids and protein), or (more probably) that she does not understand the 3D model as a representation of this. Moreover, this is the twelfth time during their problem solving process that she steps out of the particular problem they are about to solve, by trying to understand what the concepts represent, and what these mean in relation to each other. The teacher follows up Cornelia's query by questioning "the balls?" (utterance 12), while Pat says "They are proteins in your body." (utterance 13). Pat is referring to the "balls" as if these were proteins. This is actually wrong, as these represent amino acids in the 3D model.

Mark then pushes the problem solving activities forward by bringing in "the guy" they were going to help (utterance 14). He refers to the professor as suffering from hypoglycaemia. Meanwhile, Cornelia holds on to questioning the scientific concepts, and how these relate to each other, and she asks, "The protein was that the amino acids or something?" (utterance 15). The teacher spends time, follows up, and confirms that "it [the protein] is a collection of amino acids" (utterance 16). This is a correct interpretation of the phenomenon. Meanwhile, Cornelia has still not really sorted it out, and she asks for a clarification of the representation, “...what are these balls then?" (utterance 17).

Mark pushes the fulfilment of the problem forward again by saying that "now we are going to solve the next problem" (utterance 18). The teacher continues to respond to Cornelia's problematizing and he says, "It is acids or proteins" (utterance 19). This is interesting, because what seemed to be knowledgably clarified in the teacher's previous utterance (16) now seems to become confusing again. Moreover, this is also remarkable because it is only Cornelia that repeatedly raises knowledge oriented questions, and tries to discuss how these are represented in the $3 \mathrm{D}$ model. The other students do not really seem to worry about this, as long as the problem becomes solved. Finally, Fredric tells the others that he has found a hypodermic and that he will give it to the professor (utterance 20).

The same two main themes are followed up in Extract 2 as in the previous extract; solving the problem (utterances 14, 18, 20) and questioning the knowledge domain (utterances 11-13, 15-17, 19). Again, we can see that the teacher's intervention, considered as an extension of the school as curriculum deliverer, aims to ensure that all the students have understood some basic elements of the knowledge domain. The teacher makes the students accountable for sharing their knowledge with Cornelia who, at the moment, is considered as the weakest link in the group. Only one of the students (Pat) follows up this intervention. The other two have full focus on completing the problem. An interesting aspect coming from this knowledge sharing is that Cornelia again has to confirm that she has understood the procedural use of the codontable (utterance 11). This implies that the teacher has not really understood what her questioning is about, or at least that his ambition for the students' understanding of the knowledge domain is related to handling procedural aspects, and to a lesser degree, a focus on how different conceptual elements like a gene and a protein are related. The teacher's effort to perform some kind of gap-closing concerning the knowledge domain continues to be procedurally oriented, and actually contributes to excluding the possibility of the students developing scientific concepts that relate to part of a larger system (Lave 1988). Moreover, the teacher follows up Cornelia's question three times (utterances 12,16, 19). His effort to really understand and meet her knowledge based interest is unique in this particular point in their interactions, in the sense that 
it continues over several turns during their talk. However, it is the problem to be solved that wins the competition for attention, and not the knowledge domain. Mark seems confused about the teacher's, Pat's and Cornelia's problem-oriented discussion concerning the knowledge domain, and really wants to complete solving the problem (utterance 18). Fredric pursues the same problem as Mark, and he solves it by giving the professor the insulin injection (utterance 20). This results in Cornelia's question never being properly answered during this talk, and actually during the whole problem solving process. At this point in their interactions the principle of multiplicity is expressed through what the students and their teacher approach as problems, and these are, as we have seen, not the same (Ludvigsen 2007).

Further, the knowledge domain is mediating the teacher's, Pat's and Cornelia's problem solving (utterances 11-13, 15-17, 19). It is also the focus on the knowledge domain that the teacher acknowledges during this short excerpt. Meanwhile, it is interesting that even though Cornelia asks for knowledge based clarifications three times (utterances 11, 15, 17), the different answers do not overcome her confusion. First, Pat's comment tells us that she is not really aware of the difference between amino acids and proteins (utterance 13). She explains that the balls are proteins which they are not, and instead insists that they are amino acids. Second, the teacher does not deal with the knowledge domain precisely. Initially, he explains the proteins as "a collection of amino acids" (utterance 16) which is right, but then he increases the confusion again when he suddenly is not sure if the "balls" (utterance 17) are acids or proteins any more (utterance 19). Anyhow, at least the teacher confirms that Cornelia's questions concerning the knowledge domain are relevant, and this is what the gap-closing is about, and not the knowledge domain, which in some sense becomes even more confusing during this short sequence of talk (Lave 1988).

Moreover, the computer tools are mediating the students' and their teacher's talk. The design of the computer-based 3D model of what becomes an insulin-protein works as a point of reference for their effort to clarify the knowledge domain, and the relationship between scientific concepts. Cornelia talks about "build" and "balls" (utterances 11, 17), and similarly the teacher follows this up (utterance 12 and Fig. 5). These references also function as starting points for more knowledge based comments (utterances 13, 19). At the same time, and this is important, the teacher, Pat and Cornelia, who discuss the representations, all fail to explain these correctly. Furthermore, an additional element that really plays a central role in what Mark and Fredric pursue during problem solving is the overall storyline. This is evident in the concepts they use with reference to "the guy" that they would like to help (utterances 14, 20).

To sum up, there is obviously an internal tension in the school as curriculum deliverer. Partly, it organizes the group for smooth problem solving, but at the same time the inclusion of all students potentially takes a lot of time if they are to secure some kind of knowledgebased output for the students. Further, there is also a tension between interacting in the taken-for-granted computer-based 3D model of what becomes insulin, and to problematising its representations and what these entail. Finally, the limited interest of problematising the knowledge domain more than what is strictly necessary to solve the problem in the computer-based 3D model, and the overall storyline about helping the professor, intersect in a manner that supports procedural problem solving. We will argue that the storyline and the students' eagerness to solve the problem contribute to take the focus away from the content of the knowledge domain that they were meant to make sense of. The students' and the teacher's gap-closing, mediated by the different cultural tools, is dominated by how they, with as little effort as possible, can complete the problem. Moreover, it is also reasonable to claim that the 3D model comes with certain taxations, like the weaknesses concerning the conceptual representations, and the story-line that partly steals the focus away from the disciplinary problem they are asked to solve (Wertsch 1998). 


\section{Analysis three: Debriefing}

The students and their teacher have now left the computer-based 3D model, and are now sitting face-to-face in a small seminar room. They have a debriefing session about their experiences using the computer-based 3D model, the website designed to support this, and the knowledge domain. This was arranged as part of the educational setting, and was intended to give the students the possibility to talk about issues they found difficult, or that they wanted to extend, concerning the knowledge domain. We enter the area of data when the teacher has asked Cornelia if she understood the use of the "ring" (the codontable).

\section{Extract 3: Partly listening to Cornelia's question}

21. Cornelia: I understood that we were going to build bricks and so on or build upwards. I understood that and looking for all of these [amino acids]. I did not understand what insulin is or a protein is... what a, why should we find these GTA and then it becomes Met and so on? That...I understood why we did that, but not why or what it means and so on.

22. Pat: No, neither did I.

23. Cornelia: And then I didn't think that there was any point to build that thing when one doesn't understand anything.

24. Mark: I don't understand anything.

25. Fredric: Understand what?

26. Mark: Well, what, what, what is it supposed to be good for?

27. Fredric: What it is good for? You should help that guy! Because he

28. Mark: Why is it like that? Yes, why is it like that so to speak? I will never understand that. Why is it like that?

29. Pat: There should have been some links where it stood, so to speak, what you should do or what the different things meant.

30. Teacher: Mmm

31. Pat: So that you understood it better.

32. Fredric: Isn't it just that way, so to speak...

Based on the teacher's question, Cornelia clarifies what she has understood and what she did not figure out (utterance 21). She expresses that she has made sense of the procedural aspects related to identifying the correspondence between the codons and the amino acids by using the codontable, but that she has not really understood what this meant. In other words, this is a new occasion to put forward what she has been missing throughout the whole problem solving process. It is evident that she is still confused about what GTA is an expression of, what Met represents, how these relate to each other, and why she should know about it. Then, something interesting happens, because Pat, for the very first time during this participation trajectory, admits that she does not understand the subject matter either (utterance 22). Cornelia follows up, and underlines that she feels it to be pointless to take part in these kinds of procedural activities if she does not understand what it means (utterance 23). Further, Mark also expresses that he did not understand anything (utterance 24). This is in spite of the fact that we know from the previous excerpts that they all managed to use the codontable procedurally. Now, three out of four students articulate that they have problems in understanding what they have actually done during the problem solving process.

Fredric follows up the others' talk and questions "understand what?" (utterance 25). Mark tries to clarify his question, "What is it supposed to be good for?" (utterance 26). Fredric is first referring to the problem they are about to solve "What is it good for?" and 
then his answer shows that the problem he pursues refers to the storyline: "You should help the guy!" (utterance 27). Mark continues the discussion of what their procedural interactions concerning the use of the codontable implies (utterance 28). Then Pat asks for further links that could have explained what to, and how to understand, what different things meant (utterance 29). Actually, this already exists on the website, but as Extract 1 and 2 show, neither the teacher nor the students spend a lot time digging into these resources. Moreover, the teacher says "mmm" (utterance 30). This "mmm" can mean that the teacher recognizes the students' discussion and/or that he follows the talk, but realizes that he does not really understand the content of the knowledge domain himself. Anyhow, it is interesting that he does not intervene in the students' talk during this debriefing session, because the students' confusion really invites him to clarify the relationship between the conceptual elements of gene sequencing and building the insulin-protein. In this sense, he could definitely have contributed to improve the students' capability to consider conceptual elements of sequencing and building a protein in relation. Pat follows up her own previous comment, arguing that these kinds of links would make it easier (utterance 31). Finally, Fredric ends the discussion by suggesting that they could just accept the procedure they have used, and not try to make it any more complicated than it was (utterance 32). It seems as if he is not willing to admit that he has not really understood how the scientific concepts interrelate. This is confirmed in the semi-structured post-test interview, where he has a rather good understanding of separate scientific concepts, but more serious problems considering how these relate to each other.

There is only one main theme in Extract 3. The students have already solved the problem as it was formulated on the website, and the knowledge domain is therefore the only issue to question. Instead, the students enter a more conceptually oriented focus. We claim that they step out of what they have learned to identify as relevant framing for curriculum-based problem solving in schools (Mäkitalo et al. 2007). This means that they are not so restricted by the resources (how to handle a curriculum-based disciplinary problem) they have brought from one educational setting over to this situation. Rather, it finally gives them the space to listen to what Cornelia has questioned throughout the whole problem solving process in the CSCL environment (utterances 21-28). This means that at least Pat and Mark are willing to follow Cornelia's effort to step out of the situation, by trying to understand what these concepts represent, and what these mean in relation to each other. All three acknowledge that they have not really understood how different knowledge elements are related and how these are part of a larger whole, while Fredric never admits this lack of insight. The teacher's knowledge at a deeper level looks more uncertain. In sum, this means that the gap-closing concerning what they find relevant to talk about is renegotiated and has expanded compared to Extracts 1 and 2 (Lave 1988).

Also in this extract, the knowledge domain is mediating the students' and the teacher's interactions. Different scientific concepts like the protein GTA and so on are used as common reference points, and the students take positions on whether they have understood what Cornelia has questioned or not (utterances 22, 24, 26, 28). Now that the problem has been solved, Pat and Mark seem to recognize and figure out what Cornelia has struggled to get a picture of. However, they do not manage to clarify the relationship between the scientific concepts, and the teacher does not intervene either. What we see, though, is a change in their gap-closing concerning what they find relevant according to the knowledge domain (Lave 1988). They are about to understand Cornelia's curiosity about the relationship between the scientific concepts. Although they finally make a shared understanding of the problem area, they do not formulate an answer to this. This shows that the students in some sense realise that there is more unused meaning potential inscribed 
both in the computer tools, and in the knowledge domain, than they managed to realize in action (Rommetveit 1984; Linell 1998).

Further, the computer tools are mediating the students' interactions even though they have stepped out of the particular CSCL setting and are located face-to-face. This is partly made evident by how Cornelia refers to the "building bricks" and "build upwards" while trying to explicate what she has found confusing (utterance 21), but it is most obvious in the way Fredric refers to the storyline while giving an explanation for why they built the insulin "You should help the guy!" (utterance 27). Moreover, when Mark follows up his own question, "why is it like that so to speak?", Fredric does not seem to bother about the underlying scientific issues of what they have done. His actions have been at a procedural and storyline level throughout the whole problem solving process and he says, "Isn't it just that way so to speak?" (utterance 32). We will claim that this story element, that is so characteristic for these kinds of computer-based 3D models, actually, at least to some degree, brings with it certain taxations by de-emphasizing the students' focus on conceptual issues, and on how scientific concepts relate into larger systems (Wertsch 1998).

To sum up, while the students are solving the problem, this activity is the main problem to pursue, but when they leave the problem-solving mode, they spend time discussing the knowledge at a deeper level. In our data the school as curriculum deliverer partly hindered rather than stimulated the students' knowledge making in science education, at least according to the meaning potential that was inscribed in the knowledge domain, and that could have been unfolded in action (Rommetveit 1984; Linell 1998). Note how the storyline takes Fredric's attention away from the knowledge domain, and the problem he pursues is therefore how to help the professor. There is a clear tension between the knowledge domain and the storyline. In this case these represent different voices in the students' interactions (Ludvigsen 2007).

\section{Conclusion about what problems the students were pursuing}

The aim of this study has been to contribute to the discussion of students' procedural and conceptual problem solving. We have done this by investigating the complexity of what happens while a group of students solve disciplinary problems in a computer-supported collaborative learning environment. More specifically, we have looked at this as a cultural phenomenon by analyzing how different tools (the school as curriculum deliverer, the knowledge domain, the computer tools, and how these intersect) mediate the students' interactions while pursuing such a problem. By exploring selected excerpts from the students' problem solving processes, we identified what problems they found interesting to discuss and how these changed according to the presence of shifting cultural tools.

In the following four paragraphs we answer the research questions raised at the beginning of this article.

The school as curriculum deliverer and as a mediating tool in the school's practice

There are three aspects related to how the students' interactions were structured in order to deal with the school as the curriculum deliverer throughout their problem solving and during the debriefing session.

First, the school has institutionalised a practice where all students in a group are included in the disciplinary-oriented problem solving, and where they are expected to share knowledge. This is partly secured by the teacher, and to some degree by one of the students. 
Second, there is also an aim to secure a minimum level of disciplinary knowledge. An interesting issue here is that this never, based on the teacher's initiative or the continuation of other's initiative, extends the procedural character of the knowledge domain. This happens even though Cornelia challenges this kind of interpretation twelve times in less than an hour. Not even during the debriefing session does the teacher manage to broaden this procedural reading of the knowledge domain, even though this becomes an issue among three of the students. This means that even though the procedural character of the knowledge domain affords some scientific concepts; these concepts never become conceptually linked in the sense that the students get access to a larger part of the history of biological sciences hidden underneath the tip of the iceberg. It is only knowledge that is strictly necessary to solve the problem that is given attention. This brings us to the third aspect of what they find relevant to talk about, and again this is limited to the procedural characteristics of the knowledge domain, and issues related to how they can solve the problem as easily as possible. To solve the problem, with or without gaining knowledge, is the main issue the students' pursue. The knowledge-oriented discussion develops first in the debriefing session, where the problem solving no longer hinders this kind of talk.

In the students' and teachers' interactions with the school as curriculum deliverer, there is a tension between what is found to be necessary disciplinary knowledge to solve the problem and fully employing the meaning potential that is inscribed in the knowledge domain and on the website. Because the problem solving is highly procedurally-oriented, there is an extensive source of knowledge that is not used during the students' and their teacher's interactions. An obvious design challenge is to make a larger amount of the knowledge relevant, in the sense that the students might construct conceptual disciplinary knowledge. This potential that is inscribed in the knowledge domain and the website is first partly given attention after the curriculumbased problem is solved and the beginning of a conceptual discussion starts. However, this latter discussion is never completed. On this occasion it is also worth mentioning that the students defined the problem differently. Some aimed to build the insulin-protein, while others aspired to follow up the overall storyline and save the professor suffering from hypoglycaemia, and again others wanted to find out more about the knowledge domain.

The knowledge domain as a mediating tool

The knowledge domain is strongly mediating the students' problem solving interactions. The students' and their teacher follow the procedural features that characterise the codontable (see Fig. 3) as a method to solve the problem. This affords some kind of conceptual understanding, but it does not take care of the students' reflections about what it actually means, and it does not connect the scientific concepts. This implies that they use the codontable without fully understanding it or considering how this is part of a larger system. The knowledge domain is also just one of the problems the students are pursuing, and Cornelia's questioning is not really accepted before the whole group, together with their teacher, have completed the problem and entered the face-to-face debriefing session. This is interesting, because it makes the understanding of the knowledge domain secondary to solving the problem, although the attention paid to the knowledge domain increased throughout the problem solving.

Moreover, the students and their teacher used everyday concepts related to the computerbased 3D model of the insulin. If not in a consistent manner, they labelled, for example, the amino acids as balls (see Fig. 2). The concepts were also used as a common reference point, and as a marker for their understanding of the knowledge domain. This indicates that the students have made parts of the knowledge domain their own, which means that they mix 
their everyday language with more scientific concepts, and use metaphors as a way of translating between different types of language use.

The computer-based 3D models and the website designed to support this as mediating tools

There are four aspects concerning the tools that are mediating the students' problem solving, and that are also partly included in the debriefing session. The website has a large meaning potential that is only partly employed. This is probably because the inscriptions that are defined by the knowledge domain, considered in relation to the educational inscriptions, are strongly procedurally oriented. There are few, if any, parts of the design that support Cornelia's kinds of questions where she asks for a conceptual scientific clarification. This is neither taken care of in the educational setting by the teacher nor by the other students. The consequence is that the students' knowledge about the corresponding relationship between the genetic code (the insulin gene) and the insulin-protein suffers because it never becomes explicit for them. In this instance, we see an obvious potential in the formulations of the problems that the students were asked to solve and which were presented on the website. In a redesigned setting we would formulate an additional question asking the students to explicitly link the different disciplinary concepts. This could either be simple questions during their problem solving or at the end of a process in order to summarize. We think that prompting at the end of problem solving activity is a better design solution, in order to avoid interrupting the flow of activity. Students could also spend more time at the end of the problem solving sequence and return to the website in order to address how key concepts are connected.

Moreover, the computer-based 3D models, and especially the one at the molecular level of the cells, are easy enough to employ in relation to the codontable on the website, but the students and the teacher have problems explaining the different representations correctly. It seems as if the meaning potential is wider than we could wish for, because these partly contribute to confusion rather than clarity among the involved participants. Even where the knowledge domain is given, it must be negotiated and made relevant in situ (Rasmussen et al. 2005). In this sense, the students and the teacher are exposed to a knowledge potential that never gets closed, and this is probably why Cornelia's questions never really get clarified. As mentioned, we think that in future designs the teacher must be encouraged to help the students to construct scientific concepts by, for example, pointing out relevant concepts on the website. Further, the computer-based 3D model also works as a common reference point, both in their talk and in their actual building of the insulin-protein. Also, this building is procedurally oriented, and the students do not need to understand either the relationship between the codons and amino acids or the relationship between the acids and the protein. Although there are great strengths in the visualizing power of the 3D model, this tool is at the same time characterized by certain taxations, in the sense that these do not stimulate knowledge construction at the intersection between the procedural and the conceptual (Wertsch 1998). However, what the 3D models could do in a redesigned setting is to visualise the link between the codons, the aminoacids and the protein chain in an independent application, thus making explicit the disciplinary knowledge presented on the website. It is nonetheless important to emphasize that students' interpretations of these kinds of representations are never a given. This means that such initiatives always have to be supported by other kinds of interventions, such as those designed for the website or those initiated by the teacher.

Finally, this procedural aspect is also strongly supported by the story-line. One of the students seems to be most occupied with his role in this story. Even in the debriefing 
session Fredric disregards the knowledge domain, and does not want to acknowledge the other three students' recognition of Cornelia's question. His answer to the knowledgeoriented question is with reference to the suffering professor. The problem he is pursuing is anchored in the story. Both the 3D model and the story-line play central roles in the gapclosing processes. The story-line does not play the most dominant mediational role during the students' problem solving. At the same time, it is important to be particularly aware of how these kinds of stories might distract students' attention away from the disciplinary knowledge construction process rather than support it, due to their procedural orientation. The distributed setup may influence the students' procedural orientation, but since this orientation also dominates in the de-briefing session, we would argue that this is part of a general pattern of how school tasks are performed.

The intersection of the mediating cultural tools

The mediating cultural means intersect in different ways and give the students' and their teacher's interactions various directions. Below, we discuss one interdependent reinforced tendency, and four tensions with respect to this matter.

There is one main interdependent reinforced tendency. This is the procedural feature that characterises how the students' interactions were mediated by the school as curriculum deliverer, the knowledge domain and the tools as a type of social practice. These are, in short, represented by a strict focus on the problem solving; the codontable as a method to identify the correspondence between codons and amino acids and the website that in addition to presenting the knowledge domain also follows this up with educational inscriptions that are strongly delimited by the use of the codontable as a method (see Fig. 2). Finally, this is also the case for the computer-based 3D model that is designed to follow these issues up, the school as the curriculum deliverer, and how the information has been presented on the website. It is also important to mention that the analysis of Extract 3 considered in relation to Extracts 1 and 2 shows how strongly the curriculum-based problems mediate the students' problem-solving interactions and is the superior meaning compared to the knowledge domain and the computer tools. It is only after the problem is solved that some of the students spend time better understanding what Cornelia has questioned throughout their participation trajectory.

The tensions are, in general, more heterogeneous than the one dominant reinforced tendency described above. First, there is a tension between efficient problem solving and social inclusion. The school's focus on making the problem solving as smooth as possible has implications for how the students are socially included. The teacher ensures that the students have enough knowledge to take part and execute the problem, but when students withdraw because they do not get any proper answers that go beyond this, they are not given very much attention. Second, there is a tension between how to solve the curriculum based problems and how to make further elaborations. There is an unutilized meaning potential inscribed in the knowledge domain and how it is represented on the website. Third, there is a tension between how the students' take the computer-based 3D model as given, and how they struggle to explain what its representations entail. Finally, there is a tension between the story-line and the knowledge domain in cases where following the story-line becomes the problem the students' pursue. This is because it partly displaces the knowledge domain, or at least reduces the possibility for making further elaborations.

The school's problem-oriented focus has implications for the students' and their teacher's gap-closing strategies (Lave 1988). The social order is very much a result of what they find relevant to executing and fulfilling the problem. The inscribed meaning potentials 
in the knowledge domain and the computer tools are highly dominated by this problem oriented focus. How the students and their teacher decide what is relevant is very much developed in situ and in relation to this (Rommetveit 1984; Linell 1998; Rawls 2005). Moreover, it is not only the relevance potential that is negotiated in situ, but also how they conceptually interpret the knowledge domain. In our study, this understanding is strongly procedurally oriented and rejects Cornelia's effort to include a larger part of the sociocultural aspects of the phenomenon being investigated before the problem is solved.

\section{Concluding remarks}

We claim that the students' knowledge constructions in science are primarily and strongly procedurally oriented, although they solved the problem. We have documented that there are only seeds to a construction of more conceptually-oriented knowledge, although this has been a demand throughout the whole problem solving process. If we summarize the data, there are one main and two subordinate problems the students are concerned with. The most important agenda was to solve the problem, and the less important were, in prioritised order, following the story-line to help the professor and understanding the knowledge domain. The students and their teacher gained knowledge about the procedural aspects of the knowledge domain and developed everyday concepts with reference to the representations in the $3 \mathrm{D}$ model, but they did not manage to consider these in relationship in the sense of being part of a larger system. They only built conceptual knowledge that was necessary to carry out the problem. This finding is probably one of the most robust ones in the science learning domain, across different perspectives (Anderson 2007; JiménezAleixandre et al. 2000; Lehrer and Schauble 2006). In the study here the problem and the environment must be seen as rather complex, which means that the social and cognitive burden on the participants is seen as quite high. So what we need to explore further is under which conditions students go beyond what is needed in order to solve the problem and be institutionally accountable (Engle and Conant 2002; Furberg and Ludvigsen 2007).

Moreover, we actually found that the school as curriculum deliverer limited the conceptual knowledge construction, and that this intersects with the knowledge domain and the tools in a manner that supports procedural knowledge orientations. This has serious implications for how disciplinary interactions can be fostered in a more productive direction, and how future designs are planned. This is interesting when our approach is compared to a more systemic interpretation of CSCL environments with its focus on individual outcomes, interaction with specific tools, and cognitive aspects (Moss and Beatty 2006; Roschelle 1992). This latter kind of analysis would not have the possibility of bringing forward what problems the students really tried to solve, but only consider what they had understood in relation to the knowledge domain. The most important findings in our study would therefore not be raised in such a type of study, and the premises for making an improved educational setting and design would, in this regard, fail on decisive issues. Without an institutional account of the learning processes and outcomes, we risk creating idealized models of learning. What we also need to investigate further is the rather positive outcome reported by, for example, Moss and Beatty, based on their analysis of written materials and talk in synchronous CSCL environments. The relationship between text and talk is generally not emphasized in CSCL studies. Text and talk gives representation to different sources for understanding students' learning processes and outcomes.

If conceptual knowledge making is a superior aim, this must both be taken care of by different kinds of teacher interventions that encourage this kind of knowledge making and 
scaffolding strategies inscribed in the designs of the computer tools, and even these should be further expanded if necessary. The design of a synchronous CSCL environment could be considered as very advanced, since it tries to balance procedural problem solving with features that can stimulate conceptual understanding, but a design in itself cannot solve all kinds of problems. Different types of interventions must mutually stimulate interactions that support the students' understanding of scientific concepts in the educational setting and see that these are taken care of as inscriptions in the CSCL environment. These inscriptions are important in the computer-based 3D model, but are even more decisive in relation to the educational inscriptions on the website. It is these types of inscription that work as a starting point for students' participation in disciplinary-based activities. The design of the environment and resources could be based on an analysis of the students' proximal zones, both at the level of individual knowledge construction and at the level of the students as collective unit. Then, both the design of the resources and the design of the social activities can be given high priority. These two main dimensions are based on interdependency (Krange and Ludvigsen, submitted for publication; Rasmussen 2005; Valsiner and Van der Veer 2000).

In the CSCL field, different types of learning environments are designed. There are low cost applications like Roschelles' and more high cost programs such as the computer based 3D model in this study. As our analysis has demonstrated, it is not given that the high cost models improve students' knowledge constructions. However, in the $3 \mathrm{D}$ models, the students' have access to unique representations that may be seen as an important aspect in advancing their knowledge constructions. The consideration of high and low cost environments will always be an important issue during the design process, related to different practical issues such as funding schemes. Nevertheless, what we find most important, independent of the cost level, is to clarify how connections between procedural steps and conceptual orientation, which enable the students to understand the relationship between different concepts, are prompted and scaffolded in the designs of computer-based 3D models.

In CSCL research design, features and designed environments like the knowledge forum, future learning environments, and CO-LAB, just to mention a few, are based on certain formalizations or models for learning (Arnseth and Ludvigsen 2006; De Jong 2006; Wasson 2007). Such models are often based on accumulated knowledge derived from the performance of experts and high achievers. However, the models must be seen as idealized models of learning. From a dialogical and socio-cultural approach we claim that we need to be sensitive to both the interaction between the students and to the larger institutional context, not only utilizing the models as predefined. A socio-cultural stance gives us a perspective and concepts that make us sensitive to unfolding interaction over short and long stretches' of time, where students pick and make different aspects of the knowledge domain relevant, dependent upon what their peers and teachers ask for. The students' mastery and appropriation of tasks and tools is dependent on what becomes interactionally relevant for them in the different settings where they participate.

Acknowledgements We would like to thank Telenor Research and Innovation, Norway, the Network for ITResearch and Competence in Education at the University of Oslo, Norway, and InterMedia at the University of Oslo, Norway, for funding EduAction. We are especially thankful for the work the teachers and students at Ringstabekk secondary school did in relation to their participation in the design experiment. Furthermore, we are pleased with the comments given by Peter Scrimshaw, Anders Mørch, Sally Barnes and the socio-cultural research group at InterMedia, the University of Oslo, Norway. Finally, we would also like to emphasise that we have appreciated the comments that have been given in relation to the Kaleidoscope: CSCL SIG 
Workshop in Göteburg, Sweden, Dec 2005, and the Kaleidoscope: Virtual Doctoral School in Oslo, Norway, June 2006.

\section{References}

Anderson, C. (2007). Perspectives on science learning. In S. K. Abell, \& N. G. Lederman (Eds.) Handbook of research on science education (pp. 3-30). London: Erlbaum.

Andriessen, J., Baker, M., et al. (2003). Argumentation, computer support, and the educational context of confronting cognitions. In J. Andriessen, M. Baker, \& D. Suthers (Eds.) Arguing to Learn (pp. 1-26). Dordrecht: Kluwer.

Arnseth, H. C. (2004). Discourse and artefacts in learning to argue - analysing the practical management of computer supported collaborative learning. Dissertation. University of Oslo.

Arnseth, H. C., \& Ludvigsen, S. (2006). Approaching institutional contexts: systemic versus dialogic research in CSCL. International Journal of Computer-Supported Learning, 1(2), 167-185.

Brown, A. L. (1992). Design experiments: Theoretical and methodological challenges in creating complex interventions in classroom settings. Journal of the Learning Sciences, 2, 141-178.

Chi, M. T. H., Feltovich, P., \& Glaser, R. (1981). Categorization and representation of physics problems by experts and novices. Cognitive Science, 5, 121-152.

Collins, A. (1992). Towards a design science of education. In E. Scanlon, \& T. O. O’Shea (Eds.) New directions in educational technology (pp. 15-22). New York: Springer.

Collins, A., Joseph, D., et al. (2004). Design research: Theoretical and methodological issues. Journal of the Learning Sciences, 13, 15-42.

De Jong, T. (2006). Scaffolds for scientific discovery learning. In J. Elen, \& D. Clark (Eds.) Handling complexity in learning environments: research and theory (pp. 107-128). Elsevier Science: London.

Engle, R. A., \& Conant, F. R. (2002). Guiding principles for fostering productive disciplinary engagement: Explaining an emergent argument in a community of learners' classroom. Cognition and Instruction, 20, $399-483$.

Furberg, A., \& Berge, O. (2003). Collaborative Learning in Networked 3D Environments. Oslo: ITUskriftserien.

Furberg, A., \& Ludvigsen, S. (2007). Students' meaning making of socioscientific issues in computer mediated settings: Exploring learning through interaction trajectories. International Journal of Science Education (in press).

Jiménez-Aleixandre, M. P., Bugallo Rodríguez, A., \& Duschl, R. A. (2000). "Doing the lesson" or "Doing science": Argument in high school genetics. Science Education, 84, 757-792.

Jordan, B., \& Henderson, A. (1995). Interaction analysis: Foundations and practice. Journal of the Learning Sciences, 4, 39-103.

Krange, I. (2007). Computer-based 3D models in science education-Knowledge constructions. Dissertation. University of Oslo.

Krange, I., Kristiansen, T., Helljesen, L., Odegård, O., \& Fjuk, A. (2000). Samarbeidsorientert laering $i$ skolen med distriburt bruk av interaktiv 3D. Oslo: UniPub.

Kumpulainen, K., \& Wray, D. (2002). Classroom interaction and social learning. London: Routledge/ Falmer.

Lave, J. (1988). Cognition in practice: Mind, mathematics, and culture in everyday life. New York: Cambridge University Press.

Lehrer, R., \& Schauble, L. (2006). Cultivating model-based reasoning in science education. In R. K. Sawyer (Ed.) The Cambridge handbook of the learning sciences (pp. 371-387). Cambridge: Cambridge University Press.

Lemke, J. (1990). Talking science-Language, leaning, and values. London: Ablex.

Linell, P. (1998). Approaching dialogue. Talk, interaction and context in dialogical perspectives. Amsterdam: Benjamin.

Ludvigsen, S. (2007). What counts as knowledge: Learning to use categories in computer environments. In R. Säljö (Ed.), ICT and transformation of learning practices. Amsterdam: Pergamon (in press).

Ludvigsen, S., Rasmussen, I., et al. (2007). Intersecting trajectories of participation: temporality and learning. In S. Ludvigsen, A. Lund, I. Rasmussen, \& R. Säljö (Eds.) Learning across sites: new tools, infrastructures and practices. Amsterdam: Pergamon (in press).

Lund, A. (2005). Appropriation as a didactic concept: language, technology, and speech communities. Paper presented at ISCAR, Seville. 
Lund, A., \& Hauge, T. E. (2007). Changing objects in knowledge creating practices. In S. Ludvigsen, A. Lund, I. Rasmussen \& R. Säljö (Eds.), Learning across sites: New tools, infrastructures and practices. Amsterdam: Pergamon (in press).

Mäkitalo, A., Jakobsson, A., \& Säljö, R. (2007). Learning to reason in the context of socioscientific problems: Exploring the demands on students in 'new' classroom activities. In K. Kumpulainen \& $\mathrm{M}$. César (Eds.), Investigating classroom interaction: Methodological choices and challenges (in press).

Mason, L. (2007). Introduction: Bridging the cognitive and sociocultural approaches in research on conceptual change: Is it feasable? Educational Psychologist, 41(1), 1-7.

Mercer, N. (1991). Researching common knowledge: investigating the development of shared understanding in the classroom. In G. Walford (Ed.) Doing educational research (pp. 41-58). London: Routledge.

Moss, J., \& Beatty, R. (2006). Knowledge building in mathematics: Supporting collaborative learning in pattern problems. International Journal of Computer-Supported Collaborative Learning, 1, 441-165.

Rasmussen, I. (2005). Project work and ICT: Studying learning as participation trajectories. Dissertation Nr. 46, University of Oslo.

Rasmussen, I., Krange, I., \& Ludvigsen, S. (2005). The process of understanding the task: How is agency distributed between students, teachers and representations in technology-rich learning environments? International Journal of Educational Research, 39, 839-849.

Rawls, A. W. (2005). Garfinkel's conception of time. Time \& Society, 14(2/3), 163-190.

Roschelle, J. (1992). Learning by collaborating: Convergent conceptual change. The Journal of the Leaning Sciences, 2(3), 235-276.

Rommetveit, R. (1984). The Role of language in the creating and transmission of social representations. In R. Farr, \& S. Moscovici (Eds.) Social representations (pp. 331-359). Cambridge: Cambridge University Press.

Roth, W.-M. (2001). Situating cognition. Journal of the Leaning Sciences, 10, 27-61.

Scardamalia, M., \& Bereiter, C. (1994). Computer support for knowledge building communities. Journal of the Learning Sciences, 3, 265-283.

Stahl, G. (2006). Group cognition: Computer support for building collaborative knowledge. London: The MIT Press.

Säljö, R. (2000). Lärande i praktiken-ett sosiokulturelt perspektiv. Stockholm: Bokforlaget Prisma.

Valsiner, J., \& Van der Veer, R. (2000). The social mind. Construction of the idea. Cambridge, MA: Cambridge University Press.

Vosniadou, S. (1999). Conceptual change research: State of the art and future directions. In W. Schnotz, S. Vosniadou, \& M. Carretero (Eds.) New Perspectives on conceptual change. Amsterdam: Pergamon.

Vosniadou, S. (2007). The cognitive-situative divide and the problem of conceptual change. Educational Psychologist, 42(1), 55-66.

Vygotsky, L. (1978). Mind in society: The development of higher psychological processes. Cambridge, MA: Harvard University Press.

Vygotsky, L. (1986). Thought and language. Cambridge, MA: The MIT Press.

Wasson, B. (2007). Design and use of collaborative network learning scenarios: The DoCTA Experience. Journal of Educational Technology \& Society, 9(4).

Wertsch, J. V. (1991). Voices of the mind-A sociocultural approach to mediated action. Cambridge, MA: Harvard University Press.

Wertsch, J. V. (1998). Mind as action. New York: Oxford University Press.

Wertsch, J. V., del Rio, P., \& Alvarez, A. (1995). Sociocultural studies: history, action, and mediation. In J. V. Wertsch, P. del Rio, \& A. Alvarez (Eds), Sociocultural Studies of Mind. Cambridge, MA: Cambridge University Press: 1-38. 